\title{
PENGEMBANGAN KEWIRAUSAHAAN UNTUK SISWA SMA SAINT JOHN'S CATHOLIC SCHOOL MERUYA MELALUI PENINGKATAN PEMAHAMAN IDENTIFIKASI IDE BISNIS
}

\author{
Frangky Selamat ${ }^{1}$, Hetty Karunia Tunjungsari ${ }^{1}$ \\ ${ }^{1}$ Jurusan Manajemen, Universitas Tarumanagara, Jakarta \\ Email:frangkys@fe.untar.ac.id \\ Email:hettyt@fe.untar.ac.id
}

\begin{abstract}
ABSTRAK
Kegiatan pengembangan Kewirausahaan ini ditujukan untuk memberikan pemahaman kepada siswa SMA mengenai proses identifikasi ide bisnis, perumusan konsep bisnis dan penyusunan rencana bisnis yang dapat diaplikasikan secara mudah dan sederhana. Sebagian siswa SMA menganggap bahwa kewirausahaan identik dengan berjualan dan sekadar membuka usaha saja. Pemahaman yang lebih komprehensif diperlukan sehingga kewirausahaan akan memiliki nilai yang lebih aplikatif untuk kehidupan bermasyarakat. Kegiatan ini dilakukan dalam bentuk pemaparan singkat yang diikuti dengan diskusi yang melibatkan interaksi dengan peserta mengenai proses identifikasi ide bisnis dan penyusunan rencana bisnis. Selain memberikan uraian secara konseptual mengenai proses identifikasi ide bisnis, tim PKM juga akan mengajak siswa untuk mempraktikkan cara-cara menangkap peluang bisnis yang ada di sekitar mereka. Peluang bisnis dapat diterjemahkan ke dalam ide bisnis yang dapat menjadi bekal siswa untuk mengimplementasikan Kewirausahaan dalam arti yang sesungguhnya
\end{abstract}

Kata kunci: Kewirausahaan, Ide Bisnis, Siswa SMA

\section{PENDAHULUAN}

Orang muda adalah tulang punggung suatu negara. Indonesia dengan penduduk berjumlah 240 juta jiwa pada tahun 2017, menjadikan orang muda sebagai tumpuan harapan bangsa. Dengan jumlah orang muda berusia produktif berjumlah 62,4 juta jiwa yang merupakan $25 \%$ dari penduduk Indonesia, mereka memegang peranan yang amat penting bagi kemajuan bangsa. Potensi yang besar tersebut akan menjadi sia-sia jika mereka fokus pada mencari kerja dibandingkan dengan menciptakan lapangan pekerjaan bagi orang lain, atau minimal untuk dirinya sendiri. Sementara jumlah pengangguran di Indonesia pada 2016 mencapai 7,02 juta jiwa atau $5,5 \%$ dari jumlah penduduk. Orang muda menjadi bagian di dalamnya.

Salah satu cara menekan tingkat pengangguran adalah dengan menggerakkan kewirausahaan, yang harapannya adalah menciptakan wirausaha yang memberikan nilai tambah bagi perekonomian negara. Sejak 2011 pemerintah telah menjadikankan kewirausahaan sebagai gerakan nasional. Gerakan ini diharapkan dapat menyadarkan masyarakat terutama orang muda untuk menjadikan wirausaha sebagai pilihan profesi yang menjanjikan, selain menjadi profesional. Tumbuhnya kewirausahaan juga dapat membawa negara ini sejajar dengan negara maju lainnya di dunia.

Pada masa kini, beberapa negara yang menginvestasikan sejumlah besar anggarannya pada belanja R\&D justru memiliki pertumbuhan ekonomi yang rendah atau bahkan sama sekali nol (Acs, Hay \& Minniti, 2004). Sementara China menunjukkan tingkat pertumbuhan yang signifikan tanpa belanja R\&D yang tinggi (Hsiao and Shen, 2003; Dondeti \& Mohanty, 2007). Oleh karena itu, tidak selamanya belanja R\&D dapat menjamin suatu negara memiliki tingkat pertumbuhan tinggi pada masa kini. Selama beberapa dekade terakhir, hasil penelitian menunjukkan bahwa pertumbuhan ekonomi dapat dicapai lebih tinggi apabila jumlah wirausaha dalam negara tersebut meningkat (Grancia \& Zilibotti, 2005). 
Tak dapat dibantah, kewirausahaan menentukan kemakmuran suatu bangsa. Sejumlah studi memperlihatkan bahwa suatu negara membutuhkan minimal lima persen dari jumlah penduduk, berprofesi sebagai wirausaha yang dapat menciptakan kemakmuran suatu bangsa. Wirausaha yang dimaksud adalah mereka yang menjalankan usaha dengan memberikan nilai tambah di dalam bisnis yang mereka jalankan. Mereka menawarkan inovasi yang merupakan solusi bagi masyarakat luas, dan bisnis mereka terus tumbuh sehingga dapat memberikan kontribusi dalam penyediaan lapangan kerja dan pembayaran pajak kepada negara.

Sebenarnya kewirausahaan telah masuk ke dalam kurikulum nasional pada tingkat sekolah menengah atas melalui mata pelajaran Prakarya dan Kewirausahaan. Secara umum mata pelajaran ini ditujukan untuk memperkenalkan dunia kewirausahaan, namun baru sebatas membuat sebuah prakarya/pekerjaan tangan, kemudian dicoba untuk dijual kepada khalayak luas. Namun banyak hal yang tidak pas dengan konsep kewirausahaan yang sesungguhnya untuk siswa SMA. Membuka usaha dengan berjualan disetarakan dengan kewirausahaan. Pemahaman yang tidak tepat.

Dengan jumlah generasi muda yang cukup besar, potensi untuk mengembangkan kewirausahaan di kalangan ini menjadi semakin besar. Generasi muda menjadi garda terdepan. Oleh karenanya, tim PKM Untar memiliki pandangan bahwa peluang untuk mengembangkan kewirausahaan di lingkungan SMA adalah cukup besar.

Dalam survei yang dilakukan oleh tim PKM Untar di SMA Saint John, Meruya, Jakarta diidentifikasi bahwa para siswa masih memerlukan pemahaman yang lebih komprehensif mengenai kewirausahaan yang bukan hanya sekadar membuka usaha, tetapi penanaman paradigma kewirausahaan yang berbasis proses.

\section{METODE PELAKSANAAN PKM}

\section{Proses Kewirausahaan}

Paradigma mengenai kewirausahaan telah mengalami perkembangan yang begitu pesat dewasa ini. Hisrich, Peters dan Sheperd (2008) mengemukakan bahwa kewirausahaan tidak semata proses untuk membuka usaha saja. Di dalamnya terdapat proses untuk menciptakan sesuatu yang baru dan memiliki nilai dengan mengorbankan waktu dan tenaga, melakukan pengambilan risiko finansial, fisik, maupun sosial, serta menerima imbalan moneter serta kepuasan dan kebebasan pribadi. Kewirausahaan sebagai paradigma berpikir dapat diterapkan di dalam berbagai bidang kehidupan, tidak melulu di dalam diri seorang wirausaha.

Proses di dalam kewirausahaan meliputi empat proses utama yaitu (Hisrich, et.al., 2008): (1) identifikasi dan evaluasi peluang (opportunity), (2) pengembangan rencana bisnis, (3) penentuan sumber daya yang dibutuhkan, dan (4) pengelolaan usaha yang terbentuk.

Pada tahap pertama, identifikasi dan evaluasi peluang merupakan bagian krusial karena bisnis yang berhasil diawali dengan adanya peluang yang dapat dieksploitasi dengan tepat. Peluang dapat diperoleh dari berbagai sumber. Yang paling sederhana adalah dengan mengidentifikasi masalah yang ada di dalam masyarakat. Tugas seorang wirausaha adalah mencoba menawarkan solusi atas masalah tersebut dengan proposisi produk yang menarik. Selain itu peluang juga dapat diidentifikasi dari produk yang sudah ada atau tren di masa mendatang. Wirausaha menawarkan solusi atas masalah yang merupakan peluang baginya. Evaluasi terhadap peluang menjadi krusial karena tidak selalu solusi yang ditawarkan wirausaha berharga bagi calon konsumen. Tidak selalu peluang yang ada akan menjadi bisnis yang menguntungkan.

Selanjutnya pada fase kedua yaitu mengembangkan rencana bisnis. Rencana bisnis merupakan dokumen lengkap yang berisi uraian secara internal dan eksternal mengenai operasional bisnis yang akan dijalankan. Di dalamnya terdapat uraian lengkap dari aspek pasar, 
industri, pemasaran, keuangan, operasional dan sumber daya manusia. Selain itu juga kemungkinan pengembangan bisnis di masa mendatang. Yang patut diingat bahwa rencana bisnis bukanlah rencana strategis. Rencana bisnis bersifat operasional karena menjadi dasar aktivitas yang dijalankan wirausaha.

Fase ketiga adalah menentukan sumber daya yang diperlukan dalam rangka memanfaatkan peluang yang ada. Proses ini dimulai dengan menilai sumber daya yang dimiliki wirausaha. Penilaian atas sumber daya yang dimiliki amat penting karena wirausaha memulai usaha dari apa yang ia miliki terlebih dahulu. Langkah selanjutnya adalah berusaha memperoleh sumber daya yang diperlukan. Sumber daya bagi sebuah usaha rintisan (start-up) mencakup manusia seperti tim pendiri, aset fisik seperti peralatan, persediaan dan kantor atau pabrik, serta sumber daya finansial (Allen, 2012)

Fase terakhir adalah mengelola usaha yang terbentuk. Setelah usaha berjalan, tugas wirausaha adalah mengelola usahanya agar dapat terus berkelanjutan (sustainable). Di sini wirausaha dituntut memiliki kemampuan manajemen yang mumpuni. Kondisi dan tantangan yang dihadapi berbeda dibandingkan ketika wirausaha hendak mendirikan usaha.

\section{Ide Bisnis}

Awal dari proses kewirausahaan adalah pencarian ide bisnis yang layak untuk dikembangkan menjadi konsep bisnis. Ide bisnis tersebut muncul dari peluang yang ada. Wirausaha menawarkan solusi atas masalah yang ada yang melahirkan peluang bisnis.

Atas dasar konsep bisnis yang dianggap telah layak dari segi pasar, industri, produk, finansial, dan organisasi, disusun sebuah model bisnis. Konsep bisnis harus dikaji dengan cermat karena konsep yang dikembangkan belum tentu menguntungkan dan konsumen akan menyukai penawaran yang diberikan.

Model bisnis menjadi dasar untuk menyusun rencana bisnis. Model bisnis merupakan gambaran bagaimana sebuah bisnis menciptakan, menyampaikan dan menangkap nilai.

\section{Sumber Ide Bisnis}

Adapun sumber-sumber ide bisnis yang dapat dimanfaatkan oleh wirausaha terdiri atas: sumber internal dan eksternal. Sumber internal meliputi: pengalaman kerja sebelumnya, minat dan hobi pribadi, pendidikan dan keterampilan, sementara sumber eksternal seperti: peluang yang sedang terjadi, jejaring keluarga dan teman, saran dari pihak lain, aktivitas kreativitas, tren demografi, masyarakat, budaya, ekonomi dan teknik (Izard, 2006). Baik sumber internal maupun eksternal, keduanya tetap perlu dikaji kelayakannya sebelum dikembangkan menjadi rencana bisnis. Pada bagian ini wirausaha harus melakukan analisis kelayakan bisnis, yang meliputi kelayakan industri dan pasar, kelayakan produk serta kelayakan finansial (Zimmerer, Scarborough, Wilson, 2008). Analisis kelayakan bisnis menjadi syarat agar rencana bisnis yang disusun dapat efektif.

\section{Metode}

Metode pelaksanaan yang akan digunakan dalam kegiatan ini adalah sebagai berikut:

1. Pengumpulan data dan penyusunan proposal

Dalam menyusun proposal kegiatan PKM, tim melakukan wawancara dengan perwakilan dari pihak sekolah untuk mengidentifikasi masalah mitra. Setelah diketahui permasalahan yang dihadapi mitra, tim PKM melakukan studi literatur untuk mencari solusi yang tepat bagi permasalahan mitra.

2. Pelaksanaan 
Pelaksanaan kegiatan PKM adalah dengan melakukan lokakarya dan brainstorming dengan khalayak sasaran. Lokakarya terdiri dari pemaparan mengenai materi proses identifikasi ide bisnis dan diselingi oleh games terkait dengan topik identifikasi ide bisnis. Brainstorming dilakukan dengan melibatkan khalayak sasaran agar secara aktif dapat mempraktikkan pemahaman yang diperoleh selama mengikuti kegiatan PKM ke dalam kehidupan sehari-hari di lingkungan sekolah maupun masyarakat sekitar.

3. Penyusunan dan penyerahan laporan

Kegiatan ini dilaksanakan untuk para siswa SMA di Saint John's, Meruya. Tujuan kegiatan PKM adalah untuk memperkenalkan cara-cara untuk mengidentifikasi ide-ide bisnis yang mungkin dapat direalisasikan, menyusunnya menjadi konsep bisnis sederhana yang lalu dikembangkan menjadi rencana bisnis sederhana. Setelah kegiatan ini dilaksanakan maka tim PKM menyusun laporan dan menyusun draft publikasi terkait dengan kegiatan ini. Selain itu juga akan disusun modul sederhana mengenai penyusunan rencana bisnis bagi siswa SMA Modul ini nantinya akan dijadikan dasar untuk menyusun rencana kegiatan lanjutan di sekolah lain.

\section{HASIL DAN PEMBAHASAN}

Acara workshop di SMA Saint John's dibagi ke dalam dua bagian yaitu pemaparan singkat mengenai konsep kewirausahaan dan aplikasi penyusunan rencana bisnis sederhana yang didahului dengan simulasi identifikasi ide bisnis.

Pada sesi pemaparan singkat mengenai konsep kewirausahaan, siswa diarahkan untuk memahami konsep kewirausahaan secara utuh. Selama ini, sebagaimana pengakuan dari guru BP, siswa memandang kewirausahaan sebagai bagaimana menjadi pebisnis yang semata berdagang. Konsep kewirausahaan yang komprehensif bukan semata bagaimana menjadi pebisnis atau pedagang tetapi menyangkut pola pikir (mindset) kewirausahaan yaitu kreatif, inovatif, pengambilan risiko yang terkalkulasi, proaktif dan berfokus pada peluang. Pola pikir ini dapat diterapkan secara umum, tidak hanya saat berbisnis tetapi juga pada bidang pekerjaan umum. Selain itu pada sesi ini juga diuraikan mengenai bagaimana mengidentifikasi ide bisnis sebagai basis di dalam pengembangan ide dan rencana bisnis.

Pada sesi aplikasi penyusunan rencana bisnis yang didahului dengan praktik identifikasi ide bisnis, para siswa diajak untuk mengenali peluang bisnis yang ada di sekitar lingkungan mereka. Praktik "termudah" ketika mengidentifikasi ide bisnis adalah mencari masalah yang ada di dalam masyarakat dan kemudian mencoba mencari solusi atas masalah tersebut. Wacana solusi tersebut menjadi dasar dalam identifikasi ide bisnis yang lalu dikembangkan menjadi konsep dan rencana bisnis sederhana.

Seperti yang ditampilkan pada gambar 1 dan gambar 2 para siswa kelas XI yang berjumlah 17 siswa mengikuti pemaparan mengenai proses kewirausahaan. 


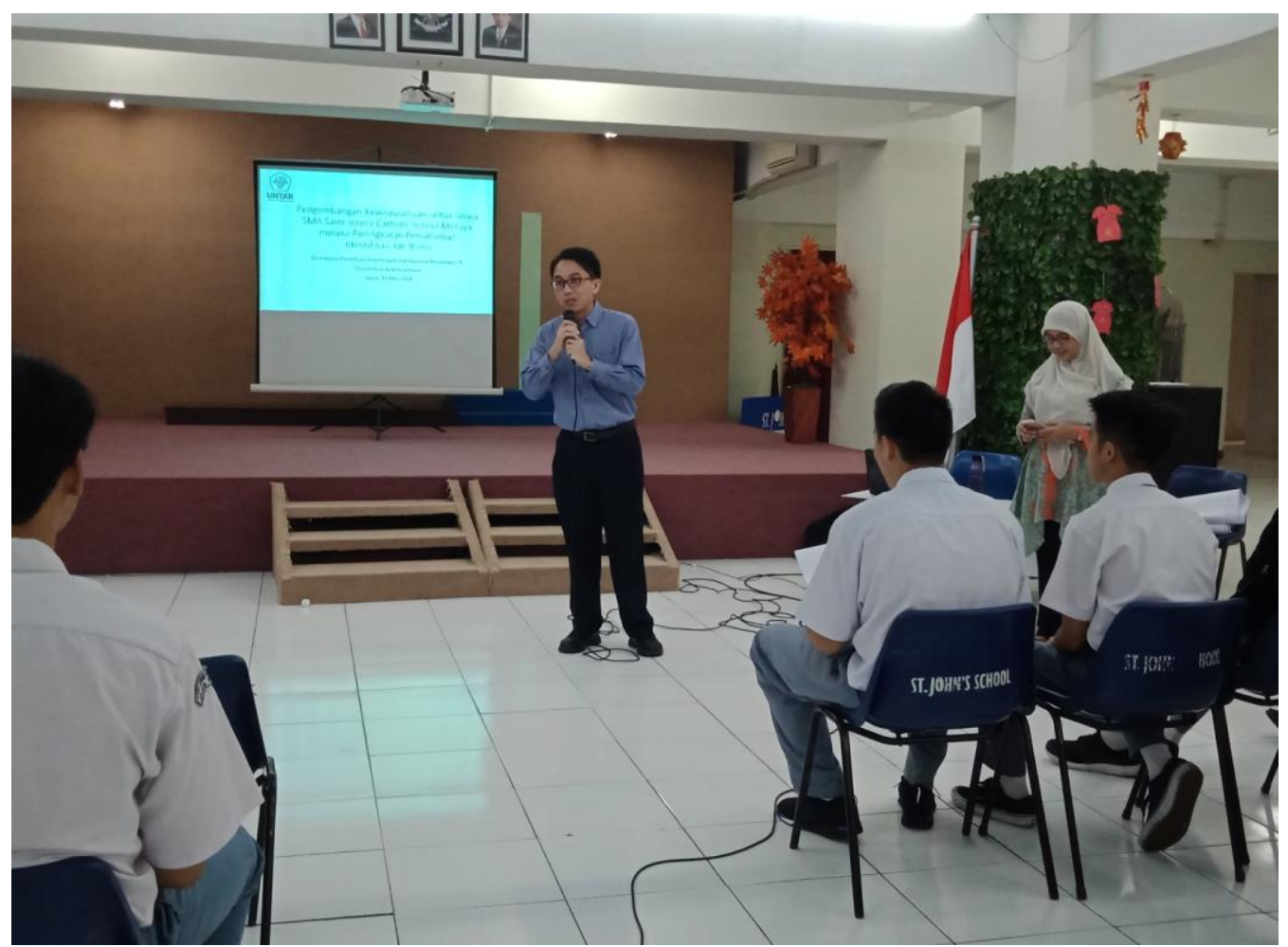

Gambar 1. Para Siswa Mengikuti Pemaparan Mengenai Kewirausahaan

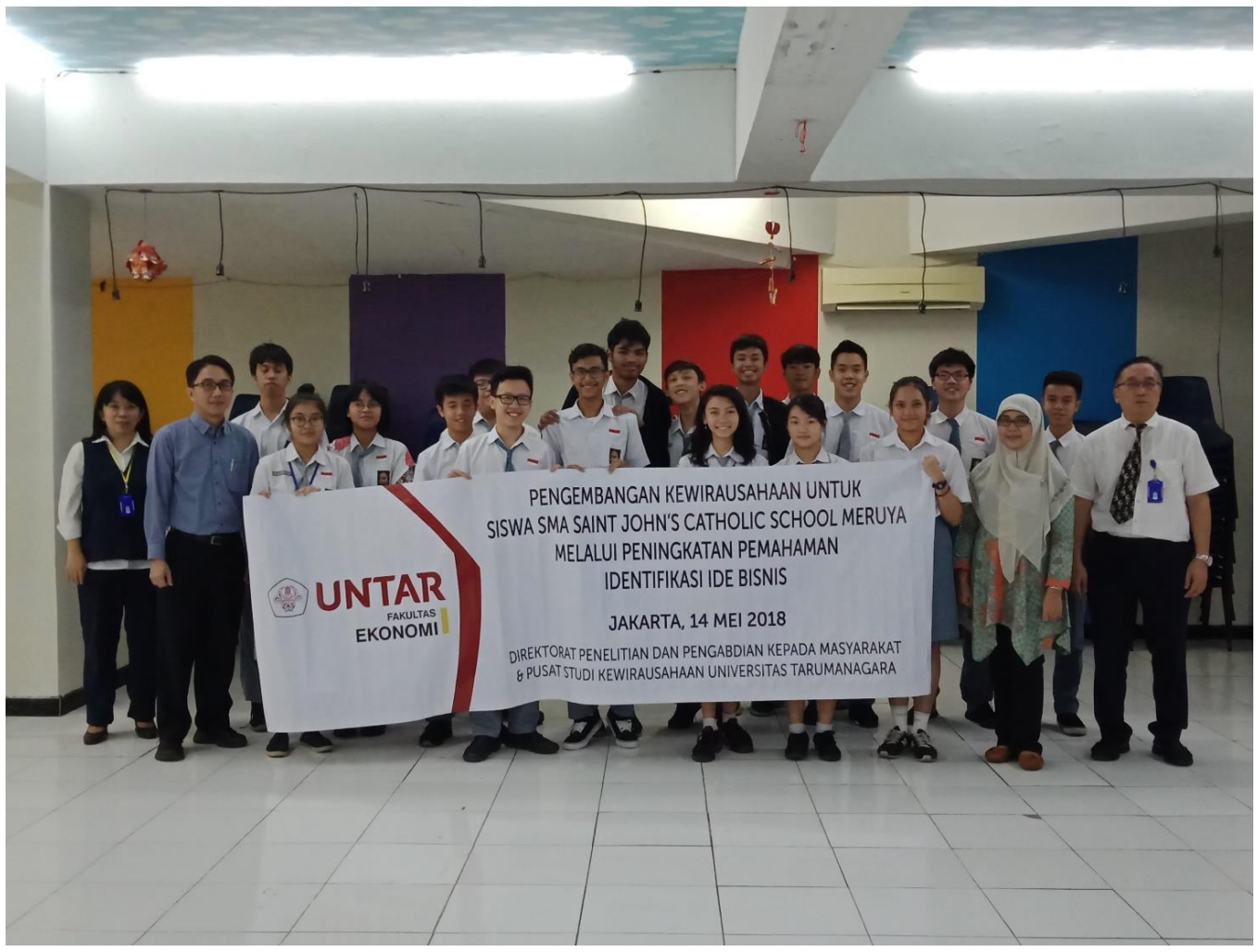

Gambar 2. Para Siswa Peserta Pelatihan Berfoto Bersama

Setelah pemaparan mengenai proses kewirausahaan, para siswa diajak untuk berdiskusi mengenai identifikasi ide bisnis yang mungkin bisa mereka rumuskan secara sederhana, dari lingkungan yang ada di sekitar mereka. Mereka didorong untuk mengumpulkan ide bisnis 
sebanyak mungkin. Dari sekian banyak ide bisnis yang terkumpul, mereka diminta untuk memilih beberapa ide bisnis yang dianggap layak untuk dikembangkan lebih lanjut menjadi konsep dan rencana bisnis sederhana. Tim PKM telah menyiapkan template sederhana mengenai rencana bisnis yang mereka susun.

Di dalam kelompok-kelompok kecil mereka berdiskusi mengenai ide, konsep dan rencana bisnis sederhana yang mungkin dapat mereka susun. Pada saat para siswa berdiskusi mengenai ide, konsep dan rencana bisnis sederhana, mereka tampak antusias. Kata "bisnis" menjadi satu daya tarik bagi siswa. Dengan menggunakan panduan yang diberikan oleh tim PKM Untar, mereka mencoba untuk menyusun sebuah rencana bisnis sederhana. Memang tidak mudah, karena mereka tidak memiliki gambaran mengenai ide bisnis yang akan mereka kembangkan. Tim PKM memandu mereka mengidentifikasi ide bisnis yang mungkin dapat mereka kembangkan. Hasilnya mereka mulai dapat merumuskan ide bisnis sederhana yang lalu mereka kembangkan menjadi rencana bisnis, apalagi terdapat siswa yang telah terbiasa melakukan penjualan secara daring sehingga makin memudahkan mereka mengidentifikasi ide bisnis.

Mengingat ini merupakan pertemuan pertama dan waktu yang sangat terbatas. maka rencana bisnis yang mereka susun belum sempat dibahas dan dipresentasikan. Rencana kegiatan pada PKM berikutnya merupakan kelanjutan dari kegiatan ini yaitu membahas rencana bisnis yang mereka susun dan kemungkinan melakukan pendampingan ketika mereka hendak melakukan tes pasar.

\section{KESIMPULAN DAN SARAN}

Setelah tim PKM Untar menyelenggarakan kegiatan pelatihan Kewirausahaan bagi para siswa SMA Saint John's, kami menyimpulkan sebagai berikut:

1. Para siswa menyambut dengan antusias kegiatan workshop kewirausahaan ini. Workshop lanjutan yang merupakan pembahasan lebih mendalam atas ide dan rencana bisnis yang telah disusun oleh para siswa, perlu dilaksanakan.

2. Para siswa memiliki intensi untuk berwirausaha yang telah mereka rintis dengan berjualan secara daring.

3. Pelajaran kewirausahaan di sekolah tidak memberikan gambaran yang lengkap mengenai kewirausahaan.

Saran yang dapat diberikan adalah sebagai berikut:

1. Diperlukan kegiatan lanjutan untuk melanjutkan workshop yang telah diadakan sebelumnya. Kegiatan lanjutan tersebut merupakan tindak lanjut atas hasil identifikasi ide bisnis dan penyusunan rencana bisnis dari para siswa.

2. Diperlukan modul untuk melaksanakan pembelajaran kewirausahaan di tingkat SMA. Modul diharapkan dapat menjadi panduan dalam pembelajaran kewirausahaan untuk para siswa SMA.

\section{UCAPAN TERIMA KASIH}

Terima kasih disampaikan kepada Direktorat Penelitian dan Pengabdian Kepada Masyarakat, Universitas Tarumanagara dan SMA St. John Meruya, Jakarta Barat

\section{REFERENSI}

Acs, Z.J., Arenius, P., Hay, M \& Minniti, M.( 2004). Global Entrepreneurship Monitor. London UK and Babson Park, MA: London Business School and Babson College.

Allen, K.R. (2012). New Venture Creation, 6th Edition, International Edition, South-Western: Cengage Learning. 
Dondeti, V.R. \& Mohanty, B.B. (2007). Impact of Foreign Direct Investment on the Gross Domestic Product, Exports and Imports of Four Asian Countries. A Panel Data Analysis. Delhi Business Review, Vol 8, No. 1 (January-June).

Grancia, G. \& Ziliboti, F. (2005). Handbook of Economic Growth. Volume 1A. Edited by Philippe Aghion and Steven N. Durlauf. Elsevier B.V.

Hisrich, R.D., Peters, M.P., Sheperd, D.A. (2008). Entrepreneurship, 7th Edition, New York: Mc.Graw-Hill

Hsiao, C. \& Shen. (2003). "Foreign Direct Investment and Economic Growth: The Importance of Institutions and Urbanization”. Economic Development and Cultural Change, Vol. 51, No 4, pp. 83-896.

Izard (2006). Opportunity Analysis, Business Ideas: Identification and Evaluation, Kansas: Acheve.

Zimmerer, T.W., Scarborough, N.M., \& Wilson, D. (2008). Essentials of Entrepreneurship and Small Business Management, 5th ed., New Jersey: Pearson/Prentice Hall. 